\title{
Analisa Pengaruh Pengaturan Kerja Operator Terhadap Pencapaian Keluaran Produksi
}

\author{
Qomarotun Nurlaila \\ Program Studi Teknik Mesin, Fakultas Teknik, Universitas Riau Kepulauan \\ qomarotun.nurlaila@yahoo.co.id
}

\begin{abstract}
Abstrak -- PT. XYZ adalah perusahaan manufaktur yang memproduksi komponen-komponen penyusun produk HDD (Hard Disk Drive). Salah satu produk yang dihasilkan oleh PT. XYZ berbahan baku karet. Produk tersebut mempunyai spesifikasi yang ketat, baik untuk ketelitian ukuran maupun untuk tampilan. Salah satu permasalahan yang dihadapi PT. XYZ adalah keluaran dari bagian pengecekan $100 \%$ yang tidak stabil meskipun jumlah sumber daya manusia yang digunakan sama dalam setiap harinya. Terjadi variasi keluaran /jam/operator dari 650 sampai 714.4 buah. Penelitian ini bertujuan menganalisa penyebab dari adanya variasi keluaran/jam/operator dan untuk mencari solusi untuk memperkecil variasi keluaran. Hasil Penelitian dapat disimpulkan bahwa penyebab adanya variasi keluaran/jam/operator adalah jumlah jenis produk yang dicek operator tidak selalu sama tiap harinya. Dimana semakin banyak jenis produk yang dicek maka semakin kecil keluaran pada hari tersebut. Untuk mendapatkan hasil yang maksimal maka operator hanya mengerjakan satu jenis produk tiap hari. Jika tidak memungkinkan maka diusahakan seminimal mungkin operator berganti jenis produk yang dicek. Perlu keahlian dari supervisor untuk mengatur kerja operator dalam upaya mendapatkan total keluaran yang maksimal.
\end{abstract}

Kata kunci: Pengaturan Kerja; Sumber Daya Manusia; dan Variasi Keluaran

Abstract -- PT. $X Y Z$ is a manufacturing company that produces the constituent components of HDD (Hard Disk Drive) products. One of the products produced by PT. XYZ made from rubber. The product has a strict specification, both for the accuracy of size and for display. One of the problems faced by PT. XYZ is the output of a $100 \%$ unstable check section even though the amount of human resources used is the same every day. There is a variation of the output / clock / operator from 650 to 714.4 pieces. This study aims to analyze the cause of the variation of output / hour / operator and to find solutions to minimize the output variation. The result of this research can be concluded that the cause of variation of output / hour / operator is the number of product type checked by operator not always the same every day. Where more and more types of products are checked then the smaller the output on that day. To get maximum results then the operator only do one type of product every day. If not possible then cultivated to a minimum operator change the type of product checked. It requires expertise from the supervisor to manage the work of the operator in an effort to get the maximum output.

Keywords: Work Settings; Human Resources; and Output Variations

\section{PENDAHULUAN}

Persaingan usaha yang semakin kompetitif membuat perusahaan mempertahankan keuntungan yang dihasilkan. Seiring itu, perusahaan dituntut untuk meningkatkan kinerjanya dengan cara mengatur sistem kerja yang lebih profesional sehingga mampu menciptakan produksi yang efektif dan efisien (Kusmindari \& Aprianto, 2009). Pengaturan sistem kerja yang baik akan meningkatkan produktivitas kerja perusahaan.

Banyak faktor-faktor yang mempengaruhi produktivitas kerja. Hakim (2011) menyatakan dalam penelitiannya bahwa kompensasi dan motivasi kerja mempunyai pengaruh yang signfikan terhadap produktivitas kerja. Sedangkan Budiasih (2012) membuat analisis bahwa struktur organisasi, budaya organisasi dan desain kerja mempunyai pengaruh yang berarti dalam produktivitas kerja. Upah, pendidikan, kemampuan kerja (Kristanto \& Manopo, 2010), semangat dan disiplin kerja (Dunggio, 2013), intensif dan keselamatan, kesehatan kerja (Munandar, 2014), kepemimpinan, job descriton (Syafii, 2015), tingkat pendidikan (Prabowo, 2016), tingkat 
pendidikan, dan keterampilan kerja (Maringan, Pongtuluran, \& Maria, 2017) merupakan beberapa faktor lain yang mempengaruhi produktivitas kerja.

Kristanto \& Manopo (2010) melakukan perancangan ulang terhadap fasilitas kerja di bagian cutting yang berdampak pada produktivitas kerja karyawan. Hal ini diperkuat (IIman \& Helianty, 2013) bahwa dengan perbaikan sistem kerja dapat meningkatkan produktivitas kerja.

Pada penelitian yang ada masih membandingkan faktor-faktor yang mempengaruhi produktivitas kerja dan perbaikan sistem kerja untuk meningkatkan kinerja karyawan. Belum banyak diketemukan penelitian yang membahas produktivitas kerja berdasarkan varian produk yang dikerjakan. Penelitian ini mencoba meneliti produktivitas kerja seseorang dilihat dari sisi varian produk yang dihasilkan.

. PT. XYZ adalah perusahaan manufaktur yang memproduksi komponen-komponen penyusun produk HDD (Hard Disk Drive). Salah satu produk yang dihasilkan oleh PT. XYZ berbahan baku karet.. Dalam upaya untuk memenuhi permintaan pelanggan maka PT. XYZ melakukan proses untuk memastikan bahwa produk yang akan dikirim ke pelanggan sesuai dengan spesifikasi yang sudah diberikan pelanggan. Beberapa langkah yang dilakukan oleh PT. XYZ antara lain dengan:melakukan pengukuran produk secara sampling (sesuai aturan yang berlaku) oleh bagian QC (Quality Control) dan melakukan pengecekan tampilan $100 \%$ oleh bagian produksi, kemudian dilanjutkan dengan pengecekan tampilan secara sampling (sesuai aturan yang berlaku) oleh bagian QC.

Salah satu permasalahan yang dihadapi PT. $\quad X Y Z$ adalah keluaran dari bagian pengecekan $100 \%$ yang tidak stabil meskipun jumlah sumber daya manusia yang digunakan sama dalam setiap harinya. Terjadi variasi keluaran /jam/operator dari 650 sampai 714.4 buah.

Dari permasalahan yang ada tersebut maka dilakukan penelitian untuk menganalisa penyebab dari adanya variasi keluaran/jam/operator dan mencari solusi untuk memperkecil variasi keluaran.

\section{METODOLOGI PENELITIAN}

Disain penelitian yang digunakan adalah gabungan dari eksploratif dan deskriptif. Sedangkan pendekatan penelitian yang digunakan adalah pendekatan deduktif yang menekankan pada detail perencanaan dalam pengumpulan data dan analisis.
Data yang digunakan adalah data sekunder yang diambil dari catatan keluaran harian dari bagian pengecekan 100\%. Data keluaran harian mencakup data keluaran dari tiap operator untuk tiap harinya.

Dalam penelitian ini akan dibahas mengenai hasil dari proses pengecekan tampilan $100 \%$ oleh bagian produksi dengan alasan karyawan yang diperlukan untuk melakukan proses ini lebih banyak dibandingkan proses yang lain (pengukuran secara sampling \& pengecekan tampilan secara sampling oleh $Q C$ ). Sehingga dengan melakukan analisa pada proses pengecekan tampilan 100\% maka akan didapatkan penyebab terjadinya variasi keluaran dan kemungkinan cara untuk memperkecil variasi keluaran. Dengan berkurangnya variasi keluaran maka diharapkan keluaran dari pengecekan $100 \%$ akan lebih stabil dan meningkat dibandingkan hasil keluaran sebelumnya. Hasil akhirnya adalah kepuasan pelanggan dengan terpenuhinya permintaan pelanggan akan pemesanan barang dan pengurangan biaya operasional perusahaan terkait dengan pengurangan jumlah karyawan. Proses kerja operator dapat dilihat pada gambar 1 di bawah ini.

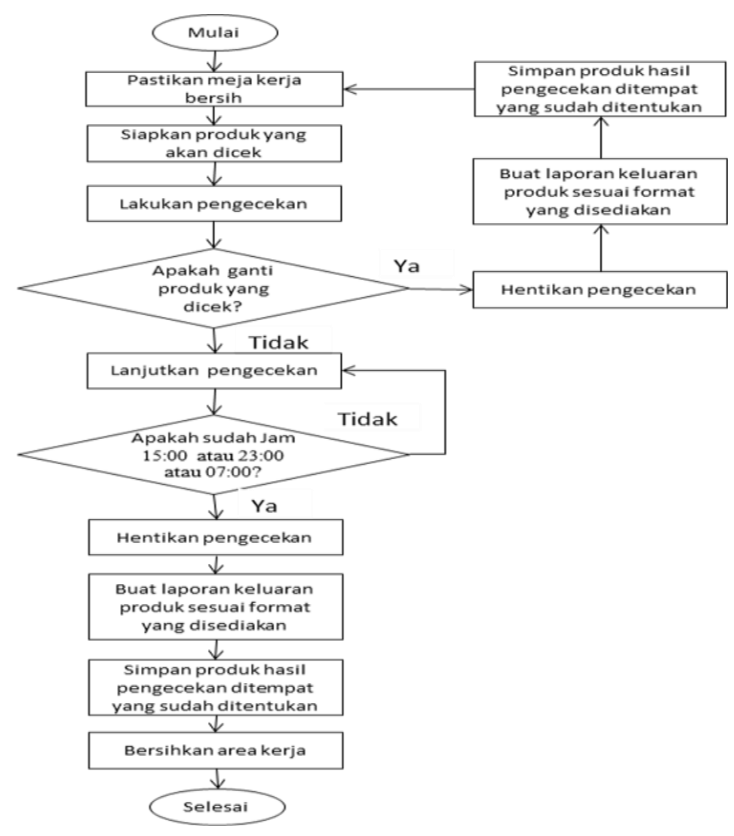

Gambar 1. Alur Kerja Operator

\section{PENGOLAHAN DATA DAN HASIL}

Penelitian dilakukan pada produk yang terbuat dari karet. Produk tersebut digunakan sebagai seal pada HDD. Agar produk seal tersebut berfungsi sesuai desain produk tersebut, maka kualitas produk seal perlu dijaga kualitasnya. Untuk menjaga kualitas produk 
tersebut maka perlu dilakukan pengukuran produk secara sampling oleh bagian QC, pengecekan tampilan $100 \%$ oleh bagian produksi dan pengecekan tampilan secara sampling oleh bagian QC

Untuk memenuhi kebutuhan bagian produksi akan operator yang mempunyai kemampuan pengecekan lebih dari 1 produk, maka setiap operator akan diberikan kualifikasi minimal bisa melakukan pengecekan tampilan $100 \%$ untuk 2 produk. Hal ini dilakukan sebagai kerja. Supervisor produksi melalui leader produksi akan melakukan pengaturan kerja dari operator sesuai dengan kebutuhan (permintaan dari bagian planning). Sehingga ada kemungkinan dalam satu hari operator mengerjakan lebih dari 1 produk, bahkan ada yang sampai 3-4 produk.

Tabel 1 menunjukkan data keluaran bagian pengecekan tampilan $100 \%$ dalam periode 1 minggu

\begin{tabular}{|c|c|c|c|c|c|c|c|}
\hline Hari kerja & Senin & Selasa & Rabu & Kamis & Jumat & Sabtu & Total \\
\hline Total Jam/Hari & 7 & 7 & 7 & 7 & 7 & 5 & 40 \\
\hline $\begin{array}{l}\text { Total Jam } \\
\text { Istirahat }\end{array}$ & $\begin{array}{l}1 \text { Jam } 10 \\
\text { Menit }\end{array}$ & $\begin{array}{l}1 \text { Jam } \\
10 \text { Menit }\end{array}$ & $\begin{array}{l}1 \text { Jam } 10 \\
\text { Menit }\end{array}$ & $\begin{array}{l}1 \text { Jam } 10 \\
\text { Menit }\end{array}$ & $\begin{array}{l}1 \text { Jam } 10 \\
\text { Menit }\end{array}$ & 1 Jam & \\
\hline \multicolumn{8}{|l|}{ Operator ke-1 } \\
\hline Item A & 5,000 & 2,500 & 3,000 & 1,000 & 1,500 & & \\
\hline Item B & & 700 & & 1,500 & 1,500 & & \\
\hline Item C & & 1,500 & & 550 & 1,700 & & \\
\hline Item D & & & 1,850 & 1,400 & & 3,600 & \\
\hline Total & 5,000 & 4,700 & 4,850 & 4,550 & 4,700 & 3,600 & \\
\hline \multicolumn{8}{|l|}{ Operator ke-2 } \\
\hline Item A & 4,500 & & & 2,500 & & & \\
\hline Item B & & 5,000 & & 2,350 & & & \\
\hline Item C & & & & & 5,000 & & \\
\hline Item D & 350 & & 5,000 & & & 3,600 & \\
\hline Total & 4,850 & 5,000 & 5,000 & 4,850 & 5,000 & 3,600 & \\
\hline \multicolumn{8}{|l|}{ Operator ke-3 } \\
\hline Item A & & & & & & 3,000 & \\
\hline Item B & 5,000 & 5,000 & & & & 500 & \\
\hline Item C & & & 2,500 & 5,000 & & & \\
\hline Item D & & & 2,350 & & 5,000 & & \\
\hline Total & 5,000 & 5,000 & 4,850 & 5,000 & 5,000 & 3,500 & \\
\hline \multicolumn{8}{|l|}{ Operator ke-4 } \\
\hline Item A & 3,500 & & & & & & \\
\hline Item B & 1,350 & & & & & 3,600 & \\
\hline Item C & & 5,000 & 5,000 & & 2,500 & & \\
\hline Item D & & & & 5,000 & 2,350 & & \\
\hline Total & 4,850 & 5,000 & 5,000 & 5,000 & 4,850 & 3,600 & \\
\hline \multicolumn{8}{|l|}{ Operator ke-5 } \\
\hline Item A & & & 1,350 & & & & \\
\hline Item B & & & & & & 3,600 & \\
\hline Item C & 5,000 & 5,000 & & & 850 & & \\
\hline Item D & & & 3,500 & 5,000 & 4,000 & & \\
\hline Total & 5,000 & 5,000 & 4,850 & 5,000 & 4,850 & 3,600 & \\
\hline \multicolumn{8}{|l|}{ Total } \\
\hline Item A & 13,000 & 2,500 & 4,350 & 3,500 & 1500 & 3,000 & \\
\hline Item B & 6,350 & 10,700 & & 3,850 & 1500 & 7,700 & \\
\hline Item C & 5,000 & 11,500 & 7,500 & 5,550 & 10,050 & 0 & \\
\hline Item D & 350 & & 12,700 & 11,400 & 11,350 & 7,200 & \\
\hline Total & 24,700 & 24,700 & 24,550 & 24,300 & 24,400 & 17,900 & \\
\hline
\end{tabular}


Dari data pada tabel 1 dapat dilihat bahwa total keluaran/hari dari operator adalah bervariasi (tidak selalu sama) dan total keluaran/hari antar operator adalah bervariasi (tidak selalu sama). Dalam penelitian ini data yang digunakan sebagai bahan untuk analisa adalah data keluaran hari Senin-Jumat, dengan mengabaikan data hari Sabtu dengan alasan variasi keluaran/hari pada setiap operator atau antar operator berkisar antara 4,550 - 5,000 buah. Range dari variasi tersebut adalah 450 buah $(5,000-4,550=450$ buah $)$.

Tabel 2 Rangkuman keluaran dari 5 orang operator dalam 1 minggu

\begin{tabular}{|l|l|l|l|l|}
\hline Operator & $\begin{array}{c}\text { Min } \\
\text { (buah) }\end{array}$ & $\begin{array}{c}\text { Max } \\
\text { (buah) }\end{array}$ & $\begin{array}{c}\text { Range } \\
\text { (buah) }\end{array}$ & $\begin{array}{c}\text { Rata-rata } \\
\text { (Buah) }\end{array}$ \\
\hline Ke-1 & 4,550 & 5,000 & 450 & 4,760 \\
\hline Ke-2 & 4,850 & 5,000 & 150 & 4,940 \\
\hline Ke-3 & 4,850 & 5,000 & 150 & 4,970 \\
\hline Ke-4 & 4,850 & 5,000 & 150 & 4,940 \\
\hline Ke-5 & 4,850 & 5,000 & 150 & 4,940 \\
\hline
\end{tabular}

Operator ke-1 mempunyai range variasi paling besar dibanding operator yang lain yaitu range variasi operator ke-1 sebesar 450 buah sedangkan range variasi operator lain sebesar 150 buah. Kondisi ini terjadi meskipun semua operator bekerja dalam waktu yang sama yaitu 7 jam / hari dan semua operator sudah terkualifikasi untuk melakukan pengecekan tampilan $100 \%$. Sehingga ada faktor lain yang mempengaruhi total keluaran dari setiap operator untuk tiap harinya.

Rata-rata keluaran dari tiap-tiap operator untuk 1 minggu berbeda-beda. Operator ke-1 mempunyai rata-rata terendah yaitu 4,760 buah. Operator ke-2, ke-4 dan ke-5 mempunyai ratarata diatas operator ke-1 yaitu 4,940 buah. Ratarata tertinggi diantara 5 orang operator didapatkan oleh operator ke-3 yaitu 4,940 buah. Sehingga perlu adanya analisa untuk mencari penyebab variasi keluaran dalam diri tiap operator dan variasi keluaran antar operator.

Tabel 3 menunjukkan hasil keluaran dari 5 operator mencakup total keluaran/hari (7 jam), jumlah jenis produk dicek/hari dan keluaran/orang/jam (produktivitas) dari tiap operator untuk waktu 1 minggu. Produktivitas dihitung dengan membagi total keluaran tiap hari dengan jumlah jenis produk yang dicek tiap hari. Dari tabel 3 dapat dilihat bahwa jumlah keluaran/hari terbesar didapatkan saat operator mengecek satu jenis produk dalam satu hari. Sedangkan jumlah keluaran /hari terkecil didapatkan saat operator mengecek empat jenis produk dalam satu hari. Ketika jumlah keluaran/hari dari operator besar maka produktivitas dari operator bersangkutan dalam hari tersebut besar. Demikian juga ketika keluaran/hari dari operator kecil maka produktivitas dari operator bersangkutan dalam hari tersebut kecil. Hal ini disebabkan karena total waktu kerja pada hari kerja yang digunakan sebagai bahan penelitian sama, yaitu dari hari Senin sampai hari Jumat adalah 7 hari untuk masing-masing hari kerja

Tabel 3 Rangkuman keluaran/hari dan jumlah jenis keluaran dicek/hari

\begin{tabular}{|l|l|l|l|l|l|l|}
\hline Hari kerja & Deskripsi & Senin & Selasa & Rabu & Kamis & Jumat \\
\hline Total Jam/Hari & & 7 & 7 & 7 & 7 & 7 \\
\hline Operator ke-1 & Keluaran/hari & 5,000 & 4,700 & 4,850 & 4,550 & 4,700 \\
\hline & Jumlah jenis Produk dicek/hari & 1 & 3 & 2 & 4 & 3 \\
\hline & Keluaran/ Orang/ Jam & 714.3 & 671.4 & 692.9 & 650.0 & 671.3 \\
\hline Operator ke-2 & Keluaran/ hari & 4,850 & 5,000 & 5,000 & 4,850 & 5,000 \\
\hline & Jumlah jenis Produk dicek/hari & 2 & 1 & 1 & 2 & 1 \\
\hline & Keluaran/ Orang/ Jam & 692.9 & 714.3 & 714.3 & 692.9 & 714.3 \\
\hline Operator ke-3 & Keluaran/ hari & 5,000 & 5,000 & 4,850 & 5,000 & 5,000 \\
\hline & Jumlah jenis Produk dicek/hari & 1 & 1 & 2 & 1 & 1 \\
\hline & Keluaran/ Orang/ Jam & 714.3 & 714.3 & 692.9 & 714.3 & 714.3 \\
\hline Operator ke-4 & Keluaran/ hari & 4,850 & 5,000 & 5,000 & 5,000 & 4,850 \\
\hline & Jumlah jenis Produk dicek/hari & 2 & 1 & 1 & 1 & 2 \\
\hline & Keluaran/ Orang/ Jam & 692.9 & 714.3 & 714.3 & 714.3 & 692.9 \\
\hline & Keluaran/ hari & 5,000 & 5,000 & 4,850 & 5,000 & 4,850 \\
\hline & Jumlah jenis Produk dicek/hari & 1 & 1 & 2 & 1 & 2 \\
\hline & Keluaran/ Orang/ Jam & 714.3 & 714.3 & 692.9 & 714.3 & 692.9 \\
\hline Total (5 Operator) & Keluaran/ hari & 24,700 & 24,700 & 24,550 & 24,300 & 24,400 \\
\hline & Jumlah jenis Produk dicek/hari & 7 & 7 & 8 & 9 & 9 \\
\hline & Keluaran/ Orang/ Jam & 705,7 & 705,7 & 701,4 & 694,3 & 697,1 \\
\hline
\end{tabular}


Dari tabel 3 dapat diketahui bahwa keluaran/hari dari operator dipengaruhi oleh jumlah jenis produk yang dicek pada hari tersebut. Semakin banyak jenis produk yang dicek dalam satu hari oleh seorang operator maka total keluaran/hari dari operator tersebut akan semakin kecil. Semakin sedikit jenis produk yang dicek dalam satu hari oleh seorang operator maka total keluaran/hari dari operator tersebut akan semakin besar.Keluaran operator akan maksimal jika operator tersebut hanya mengerjakan satu produk dalam satu hari. Sehingga dapat diambil kesimpulan bahwa banyaknya variasi jenis produk yang dikerjakan dalam satu hari adalah berbanding terbalik dengan total keluaran dalam satu hari tersebut.

Banyaknya jenis produk yang dikerjakan seorang operator ditentukan oleh atasannya. Atasan atau supervisor dari bagian pengecekan tampilan $100 \%$ mengatur operator-operator untuk mengerjakan suatu jenis produk berdasarkan tingkat kepentingan untuk memenuhi kebutuhan produk yang harus dikirimkan ke bagian planning (PPC). Tingkat kepentingan dari setiap produk untuk tiap harinya tidak sama tetapi sesuai dengan perencanaan yang dibuat oleh bagian PPC. Dalam hal ini diperlakukan keahlian supervisor untuk melakukan pengaturan kerja untuk semua operator.

Untuk memenuhi kebutuhan dari bagian PPC maka supervisor akan mengatur operatoroperator yang mengerjakan suatu produk antara lain produk $A$, produk $B$, produk $C$ dan produk $D$. Terdapat 5 operator yang terkualifikasi untuk mengecek 4 jenis produk. Pengaturan dilakukan dengan mengutamakan pengiriman harian dan juga mempertimbangkan pengiriman hari berikutnya.

Dari data penelitian diketahui bahwa jumlah jenis produk yang dicek oleh operator tidak selalu sama tiap harinya dan tidak selalu sama juga antar operator. Pengaturan kerja operator mempengaruhi keseluruhan keluaran dari bagian pengecekan tampilan $100 \%$. Total keseluruhan keluaran adalah total penjumlahan dari keluaran semua operator yang bekerja pada hari tersebut. Keluaran operator dipengaruhioleh banyaknya variasi produk yang dikerjakan dalam satu hari. Hal ini disebabkan karena adanya tahapan-tahapan yang harus dilakukan oleh operator yang harus dilakukan sebelum, saat dan setelah selesai melakukan pengecekan untuk satu jenis produk. Saat operator akan melakukan penggantian jenis produk yang akan dikerjakan, maka operator harus melakukan tahapantahapan ketika selesai melakukan pengecekan suatu produk. Setelah dipastikan tahapan- tahapan tersebut selesai dilakukan, baru kemudian operator melakukan persiapan untuk melakukan pengecekan produk berikutnya. Operator harus melakukan semua tahapan sesuai aturan yang sudah ditetapkan dengan tujuan untuk menjaga kualitas produk yaitu tidak tercampurnya produk yang satu dengan yang lain. Alur kerja dari operator dalam melakukan pekerjaannya dapat dilihat pada gambar 1 (alur kerja operator).

Ketika ada pergantian jenis produk yang dicek maka waktu kerja dari operator yang seharusnya digunakan untuk melakukan pengecekan tetapi digunakan untuk melakukan tahapan-tahapan untuk ganti jenis produk. Tahapan-tahapan tersebut meliputi tahapantahapan seperti yang dilakukan saat akhir kerja dan mengulang lagi tahapan-tahapan seperti awal kerja. Hilangnya waktu pengecekan mengakibatkan keluaran/hari berkurang, lebih kecil dibandingkan keluaran maksimal saat operator hanya mengerjakan 1 jenis produk saja (5,000 buah). Semakin sering operator berganti jenis produk maka keluaran/hari akan semakin berkurang.

Tabel 4 menunjukkan hubungan antara jumlah jenis produk yang dicek tiap hari dengan keluaran tiap hari. Terjadi hubungan linear yang berbanding terbalik, dimana semakin banyak jenis produk yang dicek maka semakin kecil keluaran pada hari tersebut. Sehingga untuk mendapatkan hasil yang maksimal maka operator hanya mengerjakan satu jenis produk tiap hari.

Tabel 4. Hubungan jenis produk dicek dan keluaran

\begin{tabular}{|c|c|c|c|c|}
\hline $\begin{array}{c}\text { Jumlah jenis } \\
\text { Produk } \\
\text { dicek/hari }\end{array}$ & 1 & 2 & 3 & 4 \\
\hline Keluaran/hari & 5,000 & 4,850 & 4,700 & 4,550 \\
\hline
\end{tabular}

Jika memungkinkan dalam 1 hari mengecek satu jenis produk, maka supervisor mengatur pelaksanaan pekerjaan operator tersebut untuk mengerjakan satu jenis produk saja. Tetapi jika tidak memungkinkan dalam 1 hari operator mengecek satu jenis produk karena berkaitan dengan kebutuhan untuk memenuhi permintaan PPC, maka diusahakan seminimal mungkin operator berganti jenis produk yang dicek. Perlu keahlian dari supervisor untuk mengatur kerja operator dalam upaya mendapatkan total keluaran yang maksimal. 


\section{KESIMPULAN}

Dari penelitian ini dapat disimpulkan bahwa penyebab adanya variasi keluaran/jam/operator adalah jumlah jenis produk yang dicek operator tidak selalu sama tiap harinya. Dimana semakin banyak jenis produk yang dicek maka semakin kecil keluaran pada hari tersebut.

Untuk mendapatkan hasil yang maksimal maka operator hanya mengerjakan satu jenis produk tiap hari. Jika tidak memungkinkan maka diusahakan seminimal mungkin operator berganti jenis produk yang dicek. Perlu keahlian dari supervisor untuk mengatur kerja operator dalam upaya mendapatkan total keluaran yang maksimal.

\section{DAFTAR PUSTAKA}

Budiasih, Y. (2012). Struktur Organisasi, Desain Kerja, Budaya Organisasi dan Pengaruhnya Terhadap Produktivitas Karyawan Studi kasus pada PT . XX di Jakarta. Jurnal Liquidity, 1(2), 99-105.

Dunggio, M. (2013). Semangat Dan Disiplin Kerja Terhadap Produktivitas Kerja Karyawan Pada PT. Jasa Raharja (Persero) Cabang Sulawesi Utara. Jurnal EMBA, 1(4), 523533.

Hakim, A. K. (2011). Pengaruh Kompensasi dan Motivasi Terhadap Produktivitas Kerja Pegawai. Jurnal Manajemen Dan Bisnis. Vol.11, No.02, 11(2), 170-184.

Ilman, A., \& Helianty, Y. (2013). Rancangan Perbaikan Sistem Kerja dengan Metode Quick Exposure Check ( QEC ) di Bengkel Sepatu X di Cibaduyut. Jurnal Online Institut Teknologi Nasional, 1(2), 120-128.

Kristanto, A., \& Manopo, R. (2010). Perancangan Ulang Fasilitas Kerja Pada Stasiun Cutting yang Ergonomis Guna Memperbaiki Produktivitas Kerja. Jurnal Informatika, $4(20,467-479$.

Kusmindari, D., \& Aprianto, A. (2009). Produktivitas dan Pengukuran Kerja Proses Produksi Medium Dencity Fibreboard (MDF). Jurnal IImiah Tekno, 6(2), 85-96.

Maringan, K., Pongtuluran, Y., \& Maria, S. (2017). Pengaruh tingkat pendidikan, sikap kerja dan keterampilan kerja terhadap prestasi kerja karyawan pt. wahana sumber lestari samarinda. AKUNTABEL, 13(2), 135-150.

Munandar, M. R. (2014). Pengaruh Keselamatn, Kesehatan Kerja dan Intensif Terhadap Motivasi dan Kinerja Karyawan (Studi Pada Pekerja Bagian Produksi PT. Sekawan karyartama Mandiri Sidoarjo). Jurnal Administrasi Bisnis, 9(1), 1-9.
Prabowo, B. P. S. (2016). Pengaruh tingkat pendidikan dan Penempatan terhadap Produktivitas Kerja Karyawan pada PT. Industri Kapal Indonesia, Bitung. Jurnal Berkala Ilmiah Efisiensi, 16(4), 738-751.

Syafii, M. (2015). Pengaruh Kepemimpinan, Job Descrition dan Kepuasan Kerja Karyawan Terhadap Produktifitas Kerja Karyawan Pada UD. Anak Agung Sedayu. Gema Ekonomi, 4(2), 126-141. 